\title{
Homeobox Protein ARX
}

National Cancer Institute

\section{Source}

National Cancer Institute. Homeobox Protein ARX. NCI Thesaurus. Code C74970.

Homeobox protein ARX (562 aa, $\sim 58 \mathrm{kDa}$ ) is encoded by the human ARX gene. This protein plays a role in transcription. 